\title{
DETERMINANTS OF PLATFORM ECOSYSTEM HEALTH: AN EXPLORATION BASED ON GROUNDED THEORY
}

\author{
Yun $\mathrm{CHEN}^{\circledR}$, Yaowu SUN $\mathbb{1}^{*}$ \\ Business School, Hunan University, Changsha, China \\ Received 21 August 2020; accepted 17 March 2021
}

\begin{abstract}
Whether the platform ecosystem operates well influences the survival and development of all actors. Drawing on the literature of business ecosystem health, we propose the topic of platform ecosystem health, which refers to a stable and sustainable operating status obtained through cooperation among actors that can effectively respond to turbulent changes, meet market demand, and make profit. Platform ecosystem health is complexly influenced by internal and external factors, and exploring these is the first step towards its improvement. To address this question, this study uses grounded theory to identify the main determinants and theoretically explain the ways in which these determinants influence platform ecosystem health. Specifically, we select 15 representative platform ecosystems in the mobile communication services, e-commerce, and high-tech manufacturing industries using theoretical sampling. Three encoding processes and theoretical saturation tests are then employed to analyze interview and secondary data on the health of these platform ecosystems. Based on the identified 132 concepts and nine categories, we obtain four types of determinants: dominant capabilities of the platform enterprise, cooperation potential of the complementary enterprise, products and services, and industry environment. We finally propose four propositions to illustrate the relationships between the determinants and platform ecosystem health.
\end{abstract}

Keywords: platform, platform ecosystem, health, platform ecosystem health, grounded theory, determinant.

JEL Classification: D21, M13, M21.

\section{Introduction}

High-tech industries are rapidly developing due to the emergence of the Internet and information technology, which have increased both technical complexity and production specialization (Tiwana, 2013). However, as no enterprise can produce all modules of a final product on its own, enterprises need to rely on platform business models to quickly meet market demand and obtain competitive advantages. Therefore, the platform ecosystem is becoming an important business organization (Tiwana, 2013), and the competition among individual

\footnotetext{
${ }^{*}$ Corresponding author. E-mail: sunyaowu@hnu.edu.cn
} 
enterprises has gradually transformed into competition among platform ecosystems (Moore, 1993). For example, in 2019, Elon Musk announced the free sharing of electric vehicle technologies, thus aiming to build a platform ecosystem by opening patents and attracting different module complementors to produce electric vehicles together.

In practice, platform ecosystems enable value-creating activities and establish governance models, whose ultimate goal is healthy development (Tiwana, 2013). In this context, platform ecosystem's "health" refers to a stable and continuous operating status, under which the platform ecosystem can face internal and external risks, meet market demand, and make profit through cooperation between member enterprises. As a result, the health of platform ecosystems influences the survival and development of hundreds of member enterprises (Iansiti \& Levien, 2002; Rietveld et al., 2019). For example, the deterioration of Nokia’s Symbian ecosystem led to large losses and even the bankruptcies of Nokia and its complementors. A platform enterprise invests significant resources to build a platform, forming a base to attract complementors to cooperate. The complementary enterprises then provide modules for this platform and are tied to the platform through specialized investments. All actors have large sunk costs and form a community with a shared future. As such, only when the platform ecosystem is healthy can the platform enterprise and its complementors continuously create and capture value (Kapoor \& Agarwal, 2017), meaning the platform ecosystem health is significant for both the ecosystem and its actors.

The topic of ecosystem health has attracted research attention. The literature largely prioritizes business ecosystem health and focuses on its theoretical descriptions (e.g., definitions and development strategies) (Adner, 2017; Iansiti \& Levien, 2002) and measures (Iansiti \& Levien, 2002, 2004a, 2004b). Subsequently, scholars mainly focused on improving these measures (den Hartigh et al., 2006) or using them to conduct case studies (Kim et al., 2014). In terms of the research on platform ecosystem health, scholars have paid attention to issues such as platform competition (Cennamo \& Santalo, 2013), innovation (Gawer \& Cusumano, 2014), and platform governance (Tiwana, 2013). Only few scholars study the determinants of the success of platform ecosystems (Kim, 2016). Platform ecosystems as anthropogenic business organizations involve the interests of all related parties and specific societal goals. They are expected to survive for longer periods than single enterprises and be healthier and more profitable, but the questions are (i) how to achieve these goals and (ii) how to maintain or improve health. Hitherto, scholars have not paid attention to these problems. Therefore, there is a need to identify the determining factors for these issues and analyze how these factors affect ecosystem health and then use human intervention to improve platform ecosystem health. Hence, we try to answer the following research questions (i) what factors affect the health of the platform ecosystem and (ii) how? Based on grounded theory, in-depth interviews and secondary data are used to systematically analyze the determinants of platform ecosystem health.

The remainder of this paper is organized as follows. Section 1 reviews the related literature. Section 2 presents the research design, including the methods, theoretical sampling, and data collection. Section 3 describes the three coding processes, tests of theoretical saturation, and credibility. Section 4 analyzes how the identified determinants influence platform ecosystem health and presents some propositions. Finally, the findings, implications, and limitations of the study are discussed in the last section. 


\section{Literature review}

\subsection{Platform ecosystem}

The ecosystem concept is derived from biological sciences (Walton, 2017). In management, Moore (1993) first proposed the concept of business ecosystem using the metaphor of ecology, holding that actors form together an economic community. Iansiti and Levien (2002) provide a detailed analysis of the operation, structure, and role of actors in business ecosystems. With the development of Web 2.0, cloud computing, and big data, platforms have become increasingly pervasive in the high-tech industry and the platform model has become a mainstream business model. With the emergence of the platform, a series of peripheral firms connect to a central platform via shared or open-source technologies and/or technical standards (Jacobides et al., 2018). Namely, they create a structure of "hub and spokes" and form the platform ecosystem. Because the platform ecosystem is a type of the business ecosystem, scholars can sometimes use the two names interchangeably (Scaringella \& Radziwon, 2018). However, the platform ecosystem has some unique characteristics, such as emergence of the platform, changes in the roles of ecosystem members, cooperation mode, and cooperation depth. The actors cooperate based on platform architecture and connect with each other through module interfaces. As a result, platform enterprises and complementors jointly complete the final product and are more interdependent (Helfat \& Raubitschek, 2018) and stickier (Rietveld et al., 2019). The platform ecosystem is more of a business community than the business ecosystem, which is a loosely connected business network (Iansiti \& Levien, 2002).

From the viewpoint of architecture, the platform and its modules constitute the platform ecosystem (Gawer \& Cusumano, 2002). Each module has no value on its own (Tiwana, 2013). However, on the platform, all modules interact through interfaces and standards to form the final product (Tiwana, 2013). From the perspective of actors, the platform ecosystem consists of the platform enterprise along with its many complementary enterprises (Gawer \& Henderson, 2007; Tiwana, 2013). These are compatible in function and are able to attain in-depth and close cooperation to complete the final product. As the founder/leader/owner of the platform ecosystem, the platform enterprise provides platforms, designs the platform architecture, masters core technologies (Gawer \& Henderson, 2007), and drives innovation at the industry level (Iansiti \& Levien, 2004b), while the complementors are the enterprises/ individuals providing complementary functions and modules for the platform enterprise. With the platform enterprise as the core and the system interface as the links, platform enterprises cooperate with complementary enterprises to create and share value.

Scholars have studied platform ecosystems from different perspectives, including leadership (Gawer \& Cusumano, 2002), strategy (Gawer \& Cusumano, 2002; Pellizzoni et al., 2019; Rietveld et al., 2019; O’Mahony \& Karp, 2020), competition (Cennamo \& Santalo, 2013), cooperation (Hannah \& Eisenhardt, 2018; Jacobides et al., 2018), governance (Inoue, 2020; Rietveld et al., 2020; Song et al., 2018), and innovation (Gawer \& Cusumano, 2014; Helfat \& Raubitschek, 2018; Panico \& Cennamo, 2020; Teece, 2018). These studies help us better understand the platform ecosystem. However, as most of them are at the actor level and focus on how actors improve their own interests, there is a lack of studies on the platform ecosystem as a whole. 


\subsection{Platform ecosystem health}

Similar to the platform ecosystem, the concept of "health" comes from the research on biological ecosystems. Healthy ecosystem is functional and sustainable and capable of maintaining its structure and function over time in the face of internal and external pressures (Mageau et al., 1995). In business research, the term "health" was first proposed by Iansiti and Levien $(2002,2004 a, 2004 b)$ to measure the overall performance of business ecosystems. If a business ecosystem is durably creating opportunities and competitive advantages for its members and other stakeholders, it is healthy (Iansiti \& Levien, 2002). Moreover, den Hartigh et al. (2006) argue that the health refers to the business ecosystem's longevity and propensity for growth, defining it as the long-term financial well-being and strength of the business ecosystem. In other words, business ecosystem health reflects the overall status of its development process, organization operation, pressure adaptation, and selfrecovery after being threatened (Iansiti \& Levien, 2002, 2004a, 2004b). Considering the literature and the attributes and characteristics of the platform ecosystem, this paper defines platform ecosystem health as a stable and sustainable operating status obtained through cooperation among actors that can effectively respond to turbulent changes, meet market demand, and make profit. This definition reflects an overall healthy state of the operations and basic sustainable development of the platform ecosystem, including whether the platform ecosystem can maintain a stable, sustainable, innovative, and active state; whether it can effectively face risks and recover itself after being threatened to maintain operation and perform its functions; whether its development process is stable and sustainable; and whether it is profitable.

Most studies focused on business ecosystem health are about measures of health (den Hartigh et al., 2006; Iansiti \& Levien, 2002, 2004a, 2004b; Kim et al., 2014) and strategies to ensure health (Iansiti \& Levien, 2004a). Specifically, to assess health, Iansiti and Levien (2002, 2004a, 2004b) propose three measures: robustness, productivity, and niche creation. den Hartigh et al. (2006) state that business ecosystem health has two main components: partner health and network health, reflecting financial well-being and network strength, respectively. The subsequent research mainly applies these measures to case studies on the health of business ecosystems (Kim et al., 2014) and software ecosystems (Jansen et al., 2009), or puts forward new ones (Jansen, 2014). Different strategies have different effects on business ecosystem health. Keystone and niche strategies improve health, while dominator strategy damages it. Iansiti and Levien (2004a) contend that enterprises should choose appropriate strategies according to their roles, thereby promoting business ecosystem health and protecting their own interests.

Studies on platform ecosystem health per se are few, with many general but not specific studies. Kim (2016) indicates that to maintain a successful platform ecosystem, platform enterprises must manage quality and build revenue structures. To improve the sustainability and resilience of a platform ecosystem, Graça and Camarinha-Matos (2017) summarize suitable performance indicators from the literature, while Kapoor and Agarwal (2017) study how platform ecosystem complexity helps complementors sustain their performance. To achieve the highest growth rate of platform ecosystems, Parker and Van Alstyne (2018) develop a model that address the trade-offs inherent in openness and innovation. 
In conclusion, on one hand, scholars provide a good foundation for the research on platform ecosystem health, extant studies promoting the healthy operation and development of platform ecosystems. On the other hand, previous research leaves some space for improvement. For example, it is not clear enough on the definition of platform ecosystem health; the main research method is the case study, which can be enriched; scholars mainly focus on measures and pay less attention to determinants, which limits the exploration of the relationship between health and other variables; existing studies mainly focus on business ecosystem health, not explicitly considering platform ecosystem health as a research topic; scholars research how the members of platform ecosystems improve performance, but studies on platform ecosystem health at the ecosystem level are still lacking. Therefore, to fill these gaps, this paper systematically defines and identifies the determinants of platform ecosystem health.

\section{Research design}

\subsection{Research method}

Grounded theory is a qualitative research method proposed by Glaser and Strauss in 1967 (Glaser \& Strauss, 1967). It is applicable to fields in which the theoretical system is imperfect and practical phenomena are difficult to explain effectively (Corbin \& Strauss, 2014; Glaser \& Strauss, 1967). It is an effective method for establishing theories (Rieger, 2019) and it has received increasing recognition and attention from mainstream academia. Because platform ecosystems have developed over a relatively short period, there is a lack of systematic theoretical foundations for them. Moreover, it is difficult to apply empirical research methods that use large samples. As such, scholars need to deeply explore business practice and analyze specific cases (Täuscher \& Laudien, 2018), for which the use of qualitative research methods to mine topics and construct theories are useful. Therefore, we adopt Corbin and Strauss's (2014) procedural grounded theory in our study.

Grounded theory has a set of strict and systematic implementation methods and principles. The research process involves defining the problem and phenomena, theoretical sampling, collecting and sorting data, coding, establishing preliminary theories, and performing theoretical saturation tests. The coding process includes open, axial, and selective coding. Grounded theory study is not confined to a certain interview object, but focuses on the continuous induction and abstraction of relevant data on research problems and establishes a theory by looking for commonalities between many interview objects.

\subsection{Theoretical sampling}

Based on theoretical sampling, 15 representative platform ecosystems are selected from the mobile communication services, e-commerce, and high-tech manufacturing industries. These industries have experienced the rapid development of their platform ecosystems (Gawer \& Cusumano, 2002). The research sample size distribution in these industries is seven (platform enterprises are A-G; complementors are P-S), five (platform enterprises are H-L; due to the homogeneity between complementary enterprises in this industry, focusing on platform 
enterprises meets the research requirements), and three (platform enterprises are M-O; complementors are Q, T, U). Overall, there are 21 enterprises involved.

This study uses in-depth interviews and secondary data collection for 11 enterprises belonging to six platform ecosystems: one in mobile communication services, two in e-commerce, and three in high-tech manufacturing. For the remaining 10 enterprises, only secondary data were collected. There are three reasons for this. First, there is little difference between the platform ecosystems of the first two industry types, so in-depth interviews from only one or two ecosystems are sufficient. The high-tech manufacturing industry shows significant differences among platform ecosystems, which necessitates in-depth interviews for all three samples. Second, the research sample is composed of world-renowned enterprises. Their secondary data from authoritative sources are thus sufficient, and the data have been monitored, questioned, and reviewed by stakeholders such as the media, the public, and employees. Due to this high reliability and credibility, the secondary data are a powerful supplement to the in-depth interview data. Third, the combination of primary and secondary data is conducive to data triangulation; it is also a requirement of grounded theory (Corbin \& Strauss, 2014). The details of the interviews are reported in Table 1.

Table 1. Interview samples information

\begin{tabular}{|c|c|c|c|c|c|c|c|}
\hline $\begin{array}{l}\text { Enter- } \\
\text { prise }\end{array}$ & $\begin{array}{c}\text { Founded } \\
\text { time }\end{array}$ & Business type & $\begin{array}{l}\text { Main intervie- } \\
\text { wee's position }\end{array}$ & $\begin{array}{l}\text { Work } \\
\text { years }\end{array}$ & Education & $\begin{array}{c}\text { Interview } \\
\text { duration }\end{array}$ & $\begin{array}{l}\text { Interview } \\
\text { method }\end{array}$ \\
\hline A & 1985 & Smart-phone & $\begin{array}{l}\text { Purchasing } \\
\text { manager }\end{array}$ & 7 & Masters & $93 \mathrm{~min}$ & Face-to-face \\
\hline $\mathrm{P}$ & 2000 & $\begin{array}{l}\text { Telecommu- } \\
\text { nication } \\
\text { network }\end{array}$ & $\begin{array}{l}\text { Operations } \\
\text { manager }\end{array}$ & 4 & Masters & $68 \mathrm{~min}$ & Telephone \\
\hline Q & 2012 & Chip & $\begin{array}{l}\text { Production } \\
\text { manager }\end{array}$ & 6 & Bachelors & $71 \mathrm{~min}$ & Telephone \\
\hline $\mathrm{R}$ & 2001 & OLED & $\begin{array}{l}\text { Operations } \\
\text { manager }\end{array}$ & 3 & Masters & $55 \mathrm{~min}$ & Video call \\
\hline $\mathrm{H}$ & 1999 & Tourism & $\begin{array}{l}\text { Operations } \\
\text { manager }\end{array}$ & 3 & Masters & $72 \mathrm{~min}$ & Telephone \\
\hline I & 1990 & $\begin{array}{l}\text { Online } \\
\text { shopping mall }\end{array}$ & $\begin{array}{l}\text { Planning } \\
\text { manager }\end{array}$ & 5 & Bachelors & $54 \mathrm{~min}$ & Telephone \\
\hline M & 1989 & Server & $\begin{array}{l}\text { Delivery } \\
\text { manager }\end{array}$ & 3 & Masters & $77 \mathrm{~min}$ & Video call \\
\hline $\mathrm{N}$ & 2000 & $\begin{array}{l}\text { Photovoltaic } \\
\text { power }\end{array}$ & $\begin{array}{l}\text { Strategy } \\
\text { manager }\end{array}$ & 4 & Masters & $75 \mathrm{~min}$ & Telephone \\
\hline $\mathrm{T}$ & 2011 & $\begin{array}{l}\text { Silver pulp/ } \\
\text { silver powder }\end{array}$ & Vice president & 9 & Masters & $190 \mathrm{~min}$ & $\begin{array}{l}\text { Face-to-face } \\
+ \text { on-site }\end{array}$ \\
\hline $\mathrm{O}$ & 1936 & $\begin{array}{l}\text { Rail transport } \\
\text { equipment }\end{array}$ & $\mathrm{R} \& \mathrm{D}$ manager & 8 & Masters & $122 \mathrm{~min}$ & $\begin{array}{l}\text { Face-to-face } \\
+ \text { on-site }\end{array}$ \\
\hline $\mathrm{U}$ & 1959 & $\begin{array}{l}\text { Rail transport } \\
\text { equipment }\end{array}$ & $\begin{array}{l}\text { Technology } \\
\text { manager }\end{array}$ & 7 & Masters & $165 \mathrm{~min}$ & $\begin{array}{l}\text { Face-to-face } \\
+ \text { on-site }\end{array}$ \\
\hline
\end{tabular}




\subsection{Data collection}

The data were collected over eight months: six months for the in-depth interviews and two months for the secondary data collection.

Twenty-three interviewees were selected. Based on the preferences of the interviewees, the in-depth interviews were conducted by telephone, video calls, face-to-face, or on-site investigation. First, an interview outline sent to the interviewees to answer consisted of detailed background knowledge and understandable professional questions. The received answers were then encoded. Next, combining the newly generated concepts and categories, we modified the interview questions. Formal interviews were then conducted using the four means highlighted above. Every interviewee was informed of the confidentiality measures taken before the interview. All recordings required the consent of the interviewees, which encouraged them to provide detailed and comprehensive information.

The interviews were semi-structured and lasted, on average, 1.5 hours. We transcribed the recordings after each interview and wrote the memos immediately. We then compared the data with the existing concepts and constantly updated the concepts, attributes, and dimensions. Then, theoretical sampling continued to increase the number of enterprises interviewed until the theory was saturated. The interviews lasted 1,042 minutes in total. The recorded data comprise around 100,000 words in Chinese.

To improve data reliability and strengthen triangulation, we collected secondary data for all samples based on the following principles.

Timeliness: The emergence and development of platform ecosystems in the three industries is a decade old. Older information is not available nor comprehensive. Hence, the data cover the period from 2010 to 2019.

Diversity: The data are drawn from the companies' websites, internal publications, articles/video/audio of interviews, autobiographies of CEOs, authoritative international business reports, business case studies, and research reports from authoritative research and advisory companies (e.g., Gartner, IDC).

Authority and reliability: Data were mainly collected from the interviewed companies and authoritative websites/newspapers/books/research institutions. Other data from unknown sources and unverified reports were excluded. Hence, from around 14,000 articles, we selected 504 with around 1 million words in Chinese.

\section{Coding process}

\subsection{Open coding}

Open coding is the first step, being the process of splitting, testing, comparing, conceptualizing, and categorizing data and materials (Corbin \& Strauss, 2014; Glaser \& Strauss, 1967). This stage begins with numbering the data. The interview data are numbered as "company code-1-statement number". The secondary data are numbered as "company code-2-article code-statement number". Then, the data are encoded word by word and sentence by sentence. To prevent omissions and distortions, we use the words of the interviewees for "invivo codes" (Corbin \& Strauss, 2014) and then conceptualize and categorize them. Through 
repeated analysis and comparison, the concepts with less occurrence, influence, and importance are eliminated. We finally obtain 132 concepts (marked with "a+ Number") and nine categories (marked with "A+ Number"). Tables 2 and 3 show the open coding results and coding examples, respectively.

Table 2. Categories and concepts of open coding

\begin{tabular}{|c|c|c|}
\hline No. & Category & Examples of concept \\
\hline A1 & $\begin{array}{l}\text { Construction } \\
\text { capability }\end{array}$ & $\begin{array}{l}\text { a11 providing a reasonable architecture; a12 building infrastructures; a13 } \\
\text { providing dominant designs and interfaces; a14 constructing good capital } \\
\text { chains; a15 attracting and selecting partners; a16 providing development } \\
\text { tools for complementors; a17 opening techniques, R\&D, patents and } \\
\text { standards to complementors, etc. }\end{array}$ \\
\hline $\mathrm{A} 2$ & $\begin{array}{l}\text { Governance } \\
\text { capability }\end{array}$ & $\begin{array}{l}\text { a21 control over the ecosystem, a2 managing partnership, a23 ability to } \\
\text { manage the industrial chain, a2 } 4 \text { control over scarce supply chains, a } 25 \\
\text { profit allocation, a } 26 \text { reaction capacity, a } 27 \text { ability to undertake risks, a28 } \\
\text { ability to deal with public relations, a29 soft power, etc. }\end{array}$ \\
\hline $\mathrm{A} 3$ & $\begin{array}{l}\text { Leadership } \\
\text { capability }\end{array}$ & $\begin{array}{l}\text { a31 opportunity recognition, a32 threat recognition, a33 seizing } \\
\text { opportunities, a34 absorptive capacity, a35 grasping user needs, a36 } \\
\text { mastering market knowledge, a37 rich professional knowledge, a38 product } \\
\text { innovation, a39 technological innovation, a310 management innovation, } \\
\text { a311 innovation culture, a312 multi-platform strategy, etc. }\end{array}$ \\
\hline A4 & $\begin{array}{l}\text { Supplement } \\
\text { capability }\end{array}$ & $\begin{array}{l}\text { a41 timely delivery of goods, a } 42 \text { technological ability, a } 43 \text { production } \\
\text { capacity, a } 44 \text { ability to withstand risk, a } 45 \text { ensuring product quality, a } 46 \\
\text { controlling cost, a } 47 \text { after-sales service, etc. }\end{array}$ \\
\hline A5 & $\begin{array}{l}\text { Cooperation } \\
\text { willingness }\end{array}$ & $\begin{array}{l}\text { a51 contract spirit, a52 cooperation spirit, a53 opportunistic behavior, a54 } \\
\text { cooperation desire, a55 strategic cooperation, a56 ordinary cooperation, etc. }\end{array}$ \\
\hline A6 & Products & $\begin{array}{l}\text { a61 operating systems, a62 hardware, a63 software, a64 final products, a65 } \\
\text { integrated products, a66 product qualities (property, reliability, safety), a67 } \\
\text { product price, etc. }\end{array}$ \\
\hline A7 & Services & $\begin{array}{l}\text { a71 cloud services, a72 software value-added services, a73 mobile } \\
\text { application search services, a74 service philosophy, a75 customer service, } \\
\text { a76 after-sales service, a77 service attitude, etc. }\end{array}$ \\
\hline A8 & $\begin{array}{l}\text { Industry } \\
\text { attributes }\end{array}$ & $\begin{array}{l}\text { a81 technology cycle time, a } 82 \text { market characteristics, a } 83 \text { customer } \\
\text { attributes, a } 84 \text { industry policies, a } 85 \text { industry development status, a } 86 \\
\text { market trends, a } 87 \text { competition degree, etc. }\end{array}$ \\
\hline A9 & $\begin{array}{l}\text { Innovation } \\
\text { environment }\end{array}$ & $\begin{array}{l}\text { a91 innovative environment for developing future pioneer technologies, a92 } \\
\text { revolutionary technology in the industry, a93 Internet }+ \text {, a94 Cloud 2.0, etc. }\end{array}$ \\
\hline
\end{tabular}

Table 3. Examples of open coding process

\begin{tabular}{|l|l|l|}
\hline \multicolumn{1}{|c|}{ Text Data } & \multicolumn{1}{|c|}{ Concept } & \multicolumn{1}{c|}{ Category } \\
\hline $\begin{array}{l}\text { B company's new FusionStage PaaS platform uses an open } \\
\text { architecture to provide an integrated development, deployment, } \\
\text { and operational management environment for enterprise } \\
\text { applications, while providing rich middleware services. (B-2-13-2) }\end{array}$ & $\begin{array}{l}\text { a11 } \\
\text { Providing } \\
\text { a platform } \\
\text { architecture }\end{array}$ & $\begin{array}{l}\text { A1 Const- } \\
\text { ruction } \\
\text { capability }\end{array}$ \\
\cline { 1 - 2 } $\begin{array}{l}\text { We set up H as a platform and then look for suppliers such as air } \\
\text { tickets and hotels to sell their products on our platform. (H-1-6, } \\
\text { 15) }\end{array}$ & $\begin{array}{l}\text { a15 } \\
\text { Attracting and } \\
\text { selecting partners }\end{array}$ & \\
\hline
\end{tabular}




\subsection{Axial coding}

Axial coding performs cluster analysis on the data divided by open coding to explore and build the potential logical relationships between categories. We classify categories of similar themes according to their relationships and logical order. Next, we screen out the most relevant categories to form the main categories and analyze the relationships and corresponding paths between the main categories and the corresponding subcategories (Corbin \& Strauss, 2014). Tables 4 and 5 report the axial coding results and coding paradigms for categories and subcategories, respectively.

Table 4. Results of axial coding

\begin{tabular}{|c|c|c|}
\hline Main category & $\begin{array}{l}\text { Corresponding } \\
\text { category }\end{array}$ & Explanation \\
\hline \multirow{3}{*}{$\begin{array}{l}\text { Dominant } \\
\text { capabilities of } \\
\text { the platform } \\
\text { enterprise }\end{array}$} & $\begin{array}{l}\text { Construction } \\
\text { capability }\end{array}$ & $\begin{array}{l}\text { By providing platform architectures, dominant designs, } \\
\text { and scarce resources, platform enterprises establish the } \\
\text { foundation for platform ecosystems }\end{array}$ \\
\hline & $\begin{array}{l}\text { Governance } \\
\text { capability }\end{array}$ & $\begin{array}{l}\text { Platform enterprises promote the development of platform } \\
\text { ecosystems by integrating resources, coordinating } \\
\text { cooperation among partners, and creating good benefit } \\
\text { distribution mechanisms }\end{array}$ \\
\hline & $\begin{array}{l}\text { Leadership } \\
\text { capability }\end{array}$ & $\begin{array}{l}\text { By improving dynamic capabilities, grasping user needs and } \\
\text { opportunities, and following the changes in the external } \\
\text { environment, platform enterprises continue to innovate; } \\
\text { they lead complementors and the entire platform ecosystem } \\
\text { continuously to gain competitive advantages }\end{array}$ \\
\hline \multirow{2}{*}{$\begin{array}{l}\text { Cooperation } \\
\text { potential of the } \\
\text { complementary } \\
\text { enterprise }\end{array}$} & $\begin{array}{l}\text { Supplement } \\
\text { capability }\end{array}$ & $\begin{array}{l}\text { The ability of complementary enterprises to supply products } \\
\text { timely and with guaranteed quality and quantity is the } \\
\text { guarantee for platform enterprises to produce final products }\end{array}$ \\
\hline & $\begin{array}{l}\text { Cooperation } \\
\text { willingness }\end{array}$ & $\begin{array}{l}\text { The willingness of complementary enterprises to establish } \\
\text { a lasting and stable strategic cooperative relationship with } \\
\text { platform enterprises is helpful in gaining benefits and } \\
\text { resisting risks together }\end{array}$ \\
\hline \multirow{2}{*}{$\begin{array}{l}\text { Products and } \\
\text { services }\end{array}$} & Products & $\begin{array}{l}\text { Product quality and price directly relate to user experience } \\
\text { and market share }\end{array}$ \\
\hline & Services & $\begin{array}{l}\text { Users no longer buy products just to obtain their functional } \\
\text { value. Additional services have become an important part of } \\
\text { users' choice and enterprises' added value }\end{array}$ \\
\hline \multirow[b]{2}{*}{$\begin{array}{l}\text { Industry } \\
\text { environment }\end{array}$} & $\begin{array}{l}\text { Industry } \\
\text { attributes }\end{array}$ & $\begin{array}{l}\text { The nature of the industry itself has a close impact on the } \\
\text { platform ecosystem within the industry }\end{array}$ \\
\hline & $\begin{array}{l}\text { Innovation } \\
\text { environment }\end{array}$ & $\begin{array}{l}\text { Innovation is an important approach to the development of } \\
\text { platform ecosystems. Whether the innovation environment } \\
\text { is good is critical to the healthy development of platform } \\
\text { ecosystems }\end{array}$ \\
\hline
\end{tabular}


Table 5. Coding paradigms for categories and subcategories

\begin{tabular}{|c|c|c|c|c|c|}
\hline $\begin{array}{l}\text { Main } \\
\text { category }\end{array}$ & $\begin{array}{l}\text { Antecedent } \\
\text { condition }\end{array}$ & Context & $\begin{array}{l}\text { Mediation } \\
\text { condition }\end{array}$ & $\begin{array}{l}\text { Action/ } \\
\text { interaction } \\
\text { strategy }\end{array}$ & Consequence \\
\hline $\begin{array}{l}\text { Dominant } \\
\text { capabilities of } \\
\text { the platform } \\
\text { enterprise }\end{array}$ & $\begin{array}{l}\text { The platform } \\
\text { enterprise is the } \\
\text { sponsor and value } \\
\text { implementer of the } \\
\text { platform ecosystem }\end{array}$ & $\begin{array}{l}\text { Participant } \\
\text { level }\end{array}$ & $\begin{array}{l}\text { Capabilities } \\
\text { to } \\
\text { construct, } \\
\text { govern, and } \\
\text { lead the } \\
\text { platform } \\
\text { ecosystem } \\
\end{array}$ & $\begin{array}{l}\text { Building the } \\
\text { platform } \\
\text { architecture, } \\
\text { grasping the } \\
\text { market demand, } \\
\text { and continuous } \\
\text { innovation } \\
\end{array}$ & $\begin{array}{l}\text { Provide the } \\
\text { foundation for } \\
\text { the operation } \\
\text { of platform } \\
\text { ecosystems }\end{array}$ \\
\hline $\begin{array}{l}\text { Cooperation } \\
\text { potential of } \\
\text { the comple- } \\
\text { mentary } \\
\text { enterprise }\end{array}$ & $\begin{array}{l}\text { Complementary } \\
\text { enterprises } \\
\text { are important } \\
\text { participants of the } \\
\text { platform ecosystem } \\
\text { and the most } \\
\text { important partners } \\
\text { of platform } \\
\text { enterprises }\end{array}$ & $\begin{array}{l}\text { Participant } \\
\text { level }\end{array}$ & $\begin{array}{l}\text { Supplement } \\
\text { capability } \\
\text { and } \\
\text { cooperation } \\
\text { willingness }\end{array}$ & $\begin{array}{l}\text { Provide quality } \\
\text { complementary } \\
\text { modules } \\
\text { continuously } \\
\text { and stably }\end{array}$ & $\begin{array}{l}\text { Establish } \\
\text { long-term and } \\
\text { stable strategic } \\
\text { cooperative } \\
\text { relationship } \\
\text { with platform } \\
\text { enterprises } \\
\text { to promote } \\
\text { the healthy } \\
\text { development } \\
\text { of platform } \\
\text { ecosystems }\end{array}$ \\
\hline $\begin{array}{l}\text { Products and } \\
\text { services }\end{array}$ & $\begin{array}{l}\text { Products and } \\
\text { services are } \\
\text { important ways } \\
\text { for platform } \\
\text { ecosystems to } \\
\text { capture market and } \\
\text { realize value }\end{array}$ & $\begin{array}{l}\text { Product } \\
\text { level }\end{array}$ & $\begin{array}{l}\text { Meet } \\
\text { market } \\
\text { demand }\end{array}$ & $\begin{array}{l}\text { Improve the } \\
\text { competitiveness } \\
\text { of products and } \\
\text { services }\end{array}$ & $\begin{array}{l}\text { Meet the } \\
\text { needs of users } \\
\text { and improve } \\
\text { the market } \\
\text { position and } \\
\text { competitiveness } \\
\text { of platform } \\
\text { ecosystems }\end{array}$ \\
\hline $\begin{array}{l}\text { Industry } \\
\text { environment }\end{array}$ & $\begin{array}{l}\text { The industrial } \\
\text { environment affects } \\
\text { the development } \\
\text { and direction of the } \\
\text { platform ecosystem }\end{array}$ & $\begin{array}{l}\text { Environ- } \\
\text { ment level }\end{array}$ & $\begin{array}{l}\text { Technology, } \\
\text { market, and } \\
\text { policy }\end{array}$ & $\begin{array}{l}\text { Technological } \\
\text { innovation, } \\
\text { market } \\
\text { development, } \\
\text { and industrial } \\
\text { policy }\end{array}$ & $\begin{array}{l}\text { Promote or } \\
\text { hinder the } \\
\text { platform } \\
\text { ecosystem }\end{array}$ \\
\hline
\end{tabular}

\subsection{Selective coding}

Selective coding discovers core categories, covering most of the research results from a theoretical perspective and then analyzes the inner relationship between core categories, main categories, and other subcategories (Corbin \& Strauss, 1990). Furthermore, we complete the conceptualized categories to compile a "story line" to describe the behavioral phenomenon and then propose a new theoretical framework (Corbin \& Strauss, 2014).

We identify the core category of "determinants of platform ecosystem health". The "story line" surrounding this core category is as follows: the healthy development of the platform ecosystem is of great significance to its participants. As the main actors, the platform enterprise and its complementors influence platform ecosystem health from different aspects. As the sponsors and initiators, platform enterprises influence the construction, governance, and 
future development of the platform ecosystem through dominant capabilities. As cooperators, complementary enterprises' ability and willingness to provide complementary products are crucial. Together, they try to produce high-quality, low-cost, and innovative products and services that help the platform ecosystem capture the market and realize value. Under a fluctuating industrial environment, these three influences will be more obvious.

\subsection{Theoretical saturation tests}

When the newly collected data can no longer contribute to conceptualization, properties of core categories, and theoretical construction, the theory is saturated; then, the data collection can stop (Corbin \& Strauss, 2014; Glaser \& Strauss, 1967). As previously mentioned, we analyze 15 platform ecosystems in three industries and the obtained categories can explain the research problem well. The samples and data continue to be collected, but yield no new findings. Therefore, we can conclude that the theoretical saturation of the framework is good.

\subsection{Credibility tests}

To ensure the credibility of our research results, we strictly comply with the requirements of grounded theory and ensure the standardization of each part as follows. (1) After the theoretical sampling, through consultation with experts and senior managers, we ensured that the interview questions were comprehensive and easy to understand. (2) Before the formal interview, we familiarized the interviewees with the interview outline. This reduced the random error considerably (Pan \& Lin, 2019). (3) Data collection followed the principle of triangulation. (4) Data collection and coding were conducted simultaneously, following the principle of constant comparison. (5) The authors coded separately, strictly adhering to the coding norms of grounded theory, so that concepts and categories emerged from data rather than from any pre-established theories (Ågård et al., 2015). For divergent coding results, the authors reached agreement after discussion. (6) New samples and data were used to test and confirm the theoretical saturation.

\section{Findings}

Platform ecosystem health is mainly influenced by four factors: dominant capabilities of the platform enterprise, cooperation potential of the complementary enterprise, products and services, and industry environment.

\subsection{Dominant capabilities of the platform enterprise}

The platform enterprise is the core of the platform ecosystem, being vital to the development of the entire ecosystem. In reality, once the platform enterprise fails, the ecosystem will collapse (West \& Wood, 2014). As the provider of the platform and builder of the platform ecosystem, its dominant capabilities have a direct impact on platform ecosystem health and reflect how the platform ecosystem is built, governed, and led. We elaborate on these three aspects below. 
Construction capability: The construction of the platform and its ecosystem is foundational to the future development of the entire platform ecosystem. First, the platform enterprise provides the architectures of the platform and ecosystem, which determine who undertakes what innovation and how much is invested in complementary products (Cusumano \& Gawer, 2002). The platform enterprise also decomposes the ecosystem into relatively independent subsystems (modules), defines the behaviors of participants, provides the basis for cooperation and integration, and establishes a mechanism to allocate innovation and benefits between participants. For example, B-2-10-5 states: "Therefore, after we enter no-man's land, we should first establish rules, which should be altruistic rather than selfish, so that we can cooperate with others better". Second, it selects complementors and provides a foundation of innovation for them. Most platform enterprises do not have the capacity to produce all complements by themselves, so they need to work with complementors (Gawer \& Cusumano, 2002).

Governance capability: After the platform ecosystem is established, the platform enterprise needs to manage it to ensure normal operation. Its governance capability mainly manifests through its coordination ability and dominant power. First, platform enterprises need complementary products to produce final products, while complementary enterprises need to realize the value of complementary products through final products. To solve cooperation disagreements and reduce transaction costs, platform enterprises need to coordinate their relationships with complementary enterprises or even make concessions. Second, to conduct effective governance, platform enterprises need to maintain their dominance in the platform ecosystem (Cusumano \& Gawer, 2002). If the platform enterprise is controlled by others and the dominant power is dispersed, decision-making conflicts will arise and the development direction will deviate. Thus, platform ecosystem health will be seriously disrupted. For example, A-1-1 states: "A used to do well with handsets, but the ecosystem was hampered by the demands and disruptions from its strategic partner, P".

Leadership capability: It is mainly embodied in dynamic capabilities, grasping the market development direction, and innovation. First, dynamic capabilities are the firm's abilities to integrate, build, and reconfigure internal and external competences to address rapidly changing environments (Teece et al., 1997), being an enterprise's source of sustained competitive advantage (Leonard-Barton, 1992). The platform ecosystem health is affected by the ability to keenly capture environmental changes and effectively respond to risks to resolve crises. Second, platform enterprises need to grasp the market demand and encourage users to participate. Users are the foundation of the platform ecosystem and thus necessary for the realization of platform ecosystem value. User needs determine what products and functions the platform ecosystem provides. User experience determines whether a product is popular in the market. Thus, users must be encouraged to participate in the innovation process and jointly create value. Finally, innovation and R\&D are the core sources of competitiveness for all platform enterprises and platform ecosystems (Helfat \& Raubitschek, 2018). For example, Xerox PARC's pioneering technology research was the source of Apple's creativity and success.

Proposition 1. Platform enterprises improve platform ecosystem health through their dominant capabilities, including construction, governance, and leadership capabilities. 


\subsection{Cooperation potential of the complementary enterprise}

The development of the platform ecosystem depends largely on innovation and the support from complementary enterprises. Therefore, the cooperation potential of complementary enterprises, composed of supplement capability and cooperation willingness, is an important determinant of platform ecosystem health.

Supplement capability: It refers to the ability to provide complementary products to platform enterprises on time, with guaranteed quality and quantity. In 2000, millions of mobile phone chips owned by Philips, a complementary enterprise, were destroyed in a fire. This event delayed deliveries, leading to a USD 1.7 billion loss for Ericsson, the platform enterprise. Ericsson withdrew from the handset market just a year later and the platform ecosystem it had built collapsed. In other words, only by ensuring the quality and quantity of complementary products can the final products be successfully brought to the market.

Cooperation willingness: Platform enterprises will invest in cooperation. However, if complementary enterprises fail to abide by their contracts, evade responsibilities, or exhibit other opportunistic behaviors, the platform enterprise and platform ecosystem will suffer losses. Therefore, the cooperation intention of complementary enterprises is particularly important, mainly reflected in specific asset investment and contract compliance. The stronger the cooperation willingness and the larger the sunk cost, the less likely opportunistic behaviors are to occur, which is conducive to long-term and stable strategic partnerships and the healthy development of a platform ecosystem. For example, N-1-35 states: "When the market is good, some complementary enterprises break the contract with us to cooperate with other companies to make more money. When the market is bad, these complementors come to me to seek cooperation and I may refuse them."

Proposition 2. Complementary enterprises improve platform ecosystem health through their cooperation potential, including supplement capability and cooperation willingness.

\subsection{Products and services}

Products and services are the embodiment of actors' cooperation and the fundamental means to meet users' needs, capture the market, and obtain revenue. Platform ecosystems are built around products and services (Hannah \& Eisenhardt, 2018). Users understand and judge the platform ecosystem by using its products and services, and the platform ecosystem builds its image and gains profits by providing quality products and services.

The competitiveness of products and services, mainly reflected by quality, price, and diversity, directly affects platform ecosystem health. By selecting better complements, platform enterprises extend the service life, promote performance and reduce the failure rate of products. They reduce cost and improve performance through good product integration scheme, then gain an advantage in price. Platform ecosystems not only provide tangible products, but also intangible services that are sometimes even core competencies. In the high-tech industry, products shift from single items to complex products that integrate hardware, software, and services. For example, F-2-7-35 states: " $F$ is committed to offering phones with high performance, but due to the lack of software and other added-value items, its market share is declining and the health of its platform ecosystem is deteriorating". Market demand is the 
driving force of the development of these platform ecosystems. For example, M-1-33 states: "We have to understand the needs of our customers, then to develop our products, including improving performance, enhancing the service, and developing new products".

Proposition 3. Tangible products and intangible services contribute directly to the platform ecosystem health.

\subsection{Industry environment}

The industry environment is a situational determinant. When it is good, the other three determinants will have a more significant impact on platform ecosystem health. Otherwise, even if these three factors remain unchanged, platform ecosystem health will decline.

Industry attributes: The basic technological cycle, market characteristics, customer attributes, and industrial policies of industries affect platform ecosystem health. The high-tech industry has different properties than other industries, such as quick technology updates and rapid changes. A new technology or function could thus trigger the transformation of the entire industry and affect the platform ecosystem. Another determinant is competitors. For example, the emergence of the iOS and Android ecosystems attracted most application developers and reduced the number of developers in the Windows Phone ecosystem. Therefore, the latter ecosystem could not provide sufficient applications, resulting in a loss of users and market share. Changes in industrial policies will change the impact of actors on the platform ecosystem. Good industrial policies have a catalytic effect, while bad ones suppress it. For example, M-1-80 states: "Our company is indigenous, so we have received a lot of policy support for our development over the years and have developed well".

Innovation environment: The "cloud 2.0 era" is an important environmental change. It reflects the "Internet + " and represents the future development direction of information technology, including the challenges and opportunities that platform ecosystems will face. Another important change is the "double creation" environment in China. China's national policy guides and encourages innovation, lays a solid foundation for all types of technologies, and thus promotes the development of the platform ecosystem.

Proposition 4. The industry environment, especially industry attributes and the innovation environment, positively affects platform ecosystem health.

\section{Conclusions}

Based on grounded theory, this study analyzes interview and secondary data from 15 platform ecosystems in three high-tech industries. Using three coding processes and theoretical saturation tests, we identify 132 concepts and nine categories, from which we derive four types of platform ecosystem health determinants. The dominant capabilities of the platform enterprise directly affect platform ecosystem health through construction, governance, and leadership. The cooperation potential of the complementary enterprises directly affects platform ecosystem health through supplement capability and cooperation willingness. Further, the products and services jointly completed by the platform enterprise and complementors affect platform ecosystem health. Platform ecosystem health is also influenced by the 
industry environment that is a situational determinant, especially in terms of industry attributes and innovation environment.

This study contributes to the literature in several ways. First, this paper focuses on the ecosystem level and defines "platform ecosystem health" as a research topic. Most extant studies are at the actor level. Instead, this paper focuses on the platform ecosystem as a whole and proposes platform ecosystem health as a research topic. This paper defines platform ecosystem health based on a literature review and in-depth interviews, providing a basis for subsequent studies and complementing the health and ecosystem theories. Second, the authors systematically study the determinants of platform ecosystem health, while the literature mainly studies individual determinants. This paper thus deepens the understanding of the platform business model, enriches the research on platform ecosystem health, and provides a theoretical basis for future large-sample empirical studies to explore the relationship between platform ecosystem health and other variables. Third, most extant research is based on a certain type of platform ecosystem. Here, three types of mature platform ecosystems are selected for the sample and their commonalities explored. The sufficient sample size and variety increase the depth, saturation, and universality of the results. Fourth, this paper uses grounded theory to study platform ecosystem health, providing a new methodological approach.

The study has many managerial implications for actors seeking platform ecosystem health. First, as the core, platform enterprises have the greatest impact on platform ecosystem health. As a result, they must constantly enhance their construction, governance, and leadership capabilities to dominate the development and transformation of the platform ecosystem. Second, complementary enterprises are important members of the platform ecosystem. They need to constantly improve their production capacities and technologies to meet the requirements of platform enterprises, and avoid opportunistic behaviors. Third, products and services are important tools for meeting market demand, which are the driving forces of platform ecosystems. By establishing user communities and forums, platform and complementary enterprises can grasp the needs of users and produce products and services with strong competitiveness. They can then improve platform ecosystem health by enhancing user experience and stickiness.

This study adopts a qualitative research method. Therefore, the authors' experiences and preferences inevitably affect the results. As purely qualitative research can only be used for theoretical construction, the generalizability of the conclusions needs to be tested in subsequent quantitative studies. In the future, researchers can use quantitative research methods to reveal the mechanisms of the identified determinants. Further, it would be meaningful to design specific scales to measure health and conceptualize and operationalize the identified categories.

\section{Funding}

This work was supported by the National Natural Science Foundation of China under Grant numbers 71872063 \& 71472061. 


\section{Author contributions}

YC and YS conceived the study and were responsible for the design and development of the data analysis. YC and YS were responsible for data collection and analysis. YC wrote the first draft of the article.

\section{Disclosure statement}

Authors have no competing financial, professional, or personal interests from other parties.

\section{References}

Adner, R. (2017). Ecosystem as structure: An actionable construct for strategy. Journal of Management, 43(1), 39-58. https://doi.org/10.1177/0149206316678451

Ågård, A. S., Egerod, I., Tønnesen, E., \& Lomborg, K. (2015). From spouse to caregiver and back: A grounded theory study of post-intensive care unit spousal caregiving. Journal of Advanced Nursing, 71(8), 1892-1903. https://doi.org/10.1111/jan.12657

Cennamo, C., \& Santalo, J. (2013). Platform competition: Strategic trade-offs in platform markets. Strategic Management Journal, 34(11), 1331-1350. https://doi.org/10.1002/smj.2066

Corbin, J. M., \& Strauss, A. L. (1990). Grounded theory research: Procedures, canons, and evaluative criteria. Qualitative Sociology, 13(1), 3-21. https://doi.org/10.1007/BF00988593

Corbin, J. M., \& Strauss, A. L. (2014). Basics of qualitative research: Techniques and procedures for developing grounded theory ( $3^{\text {rd }}$ ed.). Sage Publications. https://www.amazon.com/Basics-QualitativeResearch-Techniques-Procedures/dp/141290644X

Cusumano, M. A., \& Gawer, A. (2002). The elements of platform leadership. MIT Sloan Management Review, 43(3), 51-58. http://epubs.surrey.ac.uk/id/eprint/811215

den Hartigh, E., Tol, M., \& Visscher, W. (2006, October). The health measurement of a business ecosystem. Paper presented at the ECCON 2006 Annual Meeting. https://www.academia.edu/11105126/ The_Health_Measurement_of_a_Business_Ecosystem

Gawer, A., \& Cusumano, M. A. (2002). Platform leadership: How Intel, Microsoft, and Cisco drive industry innovation. Harvard Business School Press. https://www.amazon.com/Platform-LeadershipMicrosoft-Industry-Innovation/dp/1578515149

Gawer, A., \& Cusumano, M. A. (2014). Industry platforms and ecosystem innovation. Journal of Product Innovation Management, 31(3), 417-433. https://doi.org/10.1111/jpim.12105

Gawer, A., \& Henderson, R. (2007). Platform owner entry and innovation in complementary markets: Evidence from Intel. Journal of Economics \& Management Strategy, 16(1), 1-34. https://doi.org/10.1111/j.1530-9134.2007.00130.x

Graça, P., \& Camarinha-Matos, L. M. (2017). Performance indicators for collaborative business ecosystems - Literature review and trends. Technological Forecasting and Social Change, 116, 237-255. https://doi.org/10.1016/j.techfore.2016.10.012

Glaser, B. G., \& Strauss, A. L. (1967). The discovery of grounded theory. Aldine de Gruyter. http://www.sxf.uevora.pt/wp-content/uploads/2013/03/Glaser_1967.pdf

Helfat, C. E., \& Raubitschek, R. S. (2018). Dynamic and integrative capabilities for profiting from innovation in digital platform-based ecosystems. Research Policy, 47(8), 1391-1399.

https://doi.org/10.1016/j.respol.2018.01.019 
Hannah, D. P., \& Eisenhardt, K. M. (2018). How firms navigate cooperation and competition in nascent ecosystems. Strategic Management Journal, 39(12), 3163-3192. https://doi.org/10.1002/smj.2750

Iansiti, M., \& Levien, R. (2002). The new operational dynamics of business ecosystems: Implications for policy, operations and technology strategy (Working Paper, No. 03-030). Harvard Business School. https://www.hbs.edu/faculty/Pages/item.aspx?num=13381

Iansiti, M., \& Levien, R. (2004a). Strategy as ecology. Harvard Business Review, 82(3), 68-81. https://hbr.org/2004/03/strategy-as-ecology

Iansiti, M., \& Levien, R. (2004b). The keystone advantage: What the new dynamics of business ecosystems mean for strategy, innovation, and sustainability. Harvard Business Press. https://www.hbs.edu/faculty/Pages/item.aspx?num=16920

Inoue, Y. (2020). The effects of using existing brands in platform ecosystems. Academy of Management Proceedings, 2020(1), 19240. https://doi.org/10.5465/AMBPP.2020.19240abstract

Jacobides, M. G., Cennamo, C., \& Gawer, A. (2018). Towards a theory of ecosystems. Strategic Management Journal, 39(8), 2255-2276. https://doi.org/10.1002/smj.2904

Jansen, S., Brinkkemper, S., \& Finkelstein, A. (2009). Business network management as a survival strategy: A tale of two software ecosystems. In Proceedings of the First Workshop on Software Ecosystems (pp. 34-48). CEUR-WS. http://ceur-ws.org/Vol-505/iwseco09-5JansenBrinkkemperFinkelstein.pdf

Jansen, S. (2014). Measuring the health of open source software ecosystems: Beyond the scope of project health. Information \& Software Technology, 56(11), 1508-1519. https://doi.org/10.1016/j.infsof.2014.04.006

Kapoor, R., \& Agarwal, S. (2017). Sustaining superior performance in business ecosystems: Evidence from application software developers in the iOS and Android smartphone ecosystems. Organization Science, 28(3), 531-551. https://doi.org/10.1287/orsc.2017.1122

Kim, J. (2016). The platform business model and business ecosystem: Quality management and revenue structures. European Planning Studies, 24(12), 2113-2132. https://doi.org/10.1080/09654313.2016.1251882

Kim, K. C., Lee, S. S., Cruz, R. A. B., Enriquez, J. L. A., \& Baek, J. S. (2014). Healthiness of business ecosystem and successful platform strategy: The case of Incheon International Airport. Korea Business Review, 18, 77-110.

Leonard-Barton, D. (1992). Core capabilities and core rigidities: A paradox in managing new product development. Strategic Management Journal, 13(S1), 111-125. https://doi.org/10.1002/smj.4250131009

Mageau, M. T., Costanza, R., \& Ulanowicz, R. E. (1995). The development and initial testing a quantitative assessment of ecosystem health. Ecosystem Health, 1(4), 201-213.

https://www.researchgate.net/publication/279901558_The_development_and_initial_testing_a_ quantitative_assessment_of_ecosystem_health

Moore, J. F. (1993). Predators and prey: A new ecology of competition. Harvard Business Review, 71(3), 75-86. https://www.researchgate.net/publication/13172133

O'Mahony, S., \& Karp, R. (2020). From proprietary to collective governance: How do platform participation strategies evolve? Strategic Management Journal, 1-33. https://doi.org/10.1002/smj.3150

Pan, J., \& Lin, J. (2019). Construction of network entrepreneurial platform leadership characteristics model: Based on the grounded theory. Journal of Business Economics and Management, 20(5), 958-978. https://doi.org/10.3846/jbem.2019.10618

Panico, C., \& Cennamo, C. (2020). User preferences and strategic interactions in platform ecosystems. Strategic Management Journal, 1-23. https://doi.org/10.1002/smj.3149

Parker, G., \& Van Alstyne, M. (2018). Innovation, openness, and platform control. Management Science, 64(7), 3015-3032. https://doi.org/10.1287/mnsc.2017.2757 
Pellizzoni, E., Trabucchi, D., \& Buganza, T. (2019). Platform strategies: How the position in the network drives success. Technology Analysis \& Strategic Management, 31(5), 579-592. https://doi.org/10.1080/09537325.2018.1524865

Rieger, K. L. (2019). Discriminating among grounded theory approaches. Nursing Inquiry, 26(1), 1-12. https://doi.org/10.1111/nin.12261

Rietveld, J., Ploog, J. N., \& Nieborg, D. B. (2020). Coevolution of platform dominance and governance strategies: Effects on complementor performance outcomes. Academy of Management Discoveries, 6(3), 488-513. https://doi.org/10.5465/amd.2019.0064

Rietveld, J., Schilling, M. A., \& Bellavitis, C. (2019). Platform strategy: Managing ecosystem value through selective promotion of complements. Organization Science, 30(6), 1232-1251. https://doi.org/10.1287/orsc.2019.1290

Scaringella, L., \& Radziwon, A. (2018). Innovation, entrepreneurial, knowledge, and business ecosystems: Old wine in new bottles?. Technological Forecasting and Social Change, 136, 59-87. https://doi.org/10.1016/j.techfore.2017.09.023

Song, P., Xue, L., Rai, A., \& Zhang, C. (2018). The ecosystem of software platform: A study of asymmetric cross-side network effects and platform governance. MIS Quarterly, 42(1), 121-142. https://doi.org/10.25300/misq/2018/13737

Täuscher, K., \& Laudien, S. M. (2018). Understanding platform business models: A mixed methods study of marketplaces. European Management Journal, 36(3), 319-329. https://doi.org/10.1016/j.emj.2017.06.005

Teece, D. J., Pisano, G., \& Shuen, A. (1997). Dynamic capabilities and strategic management. Strategic Management Journal, 18(7), 509-533. https://doi.org/10.1002/(SICI)1097-0266(199708)18:7<509::AID-SMJ882>3.0.CO;2-Z

Teece, D. J. (2018). Profiting from innovation in the digital economy: Enabling technologies, standards, and licensing models in the wireless world. Research Policy, 47(8), 1367-1387. https://doi.org/10.1016/j.respol.2017.01.015

Tiwana, A. (2013). Platform ecosystems: Aligning architecture, governance, and strategy ( $\left.1^{\text {st }} \mathrm{ed}\right)$. Morgan Kaufmann.

Walton, N. (2017). The Internet as a technology-based ecosystem: A new approach to the analysis of business, markets and industries. Palgrave Macmillan. https://doi.org/10.1057/978-1-137-60077-6

West, J., \& Wood, D. (2014). Evolving an open ecosystem: The rise and fall of the Symbian platform. In Advances in strategic management: Vol. 30. Collaboration and competition in business ecosystems (pp. 27-67). Emerald Group Publishing Limited. https://doi.org/10.1108/S0742-3322(2013)0000030005 